\title{
PENGEMBANGAN MASYARAKAT DI BIDANG EKONOMI MELALUI MIGRASI Studi Pola Migrasi Pedagang Burjo asal Sindangagung dan Garawangi Kuningan di Yogyakarta
}

\author{
Asep Kurniawan \\ Staf Pengajar Institut Agama Islam Negeri Syekh Nurjati Cirebon \\ asepkurniawan@syekhnurjati.ac.id
}

\begin{abstract}
This research traced the migration of green bean porridge traders in Yogyakarta, why were they from Kuningan?To answer this question, things related to migration, such as type, motivation and purpose, need to be answered by research. The used theories were push-pull theory and chain theory. This study was an anthropological qualitative study with ethnographic methods.The research findings showed that green bean porridge traders in Papringan were migrant groups from Kuningan who built a network of group relations. This network was formally proven by the existence of an association (paguyuban Arya Kemuning) which accommodated green bean porridge traders. Implicitly, the network of green bean porridge traders could be seen from a sense of mechanical solidarity, which was formed by regional ethnicity. The chosen circulational migration was another proof of the existence of green bean porridge traders network in Yogyakarta. It was used as a solution for community development for economic prosperity.
\end{abstract}

Keywords: Brotherhood, Hard Work, Solidarity, Motivation 


\section{A. Latar Belakang Masalah}

Dalam sebuah penelitian yang dilakukan Korff (1994: 214-217) tentang para pedagang di Bangkok, Thailand, ditemukan bahwa orang-orang yang bekerja di sektor informal ini akan terintegrasi dalam sebuah jaringan relasi interpersonal. Integrasi ini terjadi di antara orang-orang yang ada pada posisi yang sama, bekerja sebagai pedagang. Selanjutnya relasi interpersonal dalam jaringan tersebut memberi kesempatan kepada para pedagang untuk meningkatkan usahanya. Oleh karena itu, para pedagang yang tergolong dalam jaringan tersebut akan berusaha memelihara dan lebih mempererat relasi yang sudah ada.

Selain itu terintegrasi dalam sebuah jaringan kelompok, para pedagang juga tidak jarang merupakan kelompok migrasi yang berusaha mempertahankan hidup di daerah lain. Menurut Naim (1979: 1) masyarakat modern sukar dipahami tanpa menghubungkannya dengan gerakan migrasi (perpindahan penduduk) di tiap negara. Di Indonesia misalnya, kebanyakan daerah-daerahnya mempunyai kelompok-kelompok minoritas etnis sebagai akibat dari adanya mobililtas penduduk.

Sebagai bagian dari mata pencaharian hidup, pedagang tentunya tidak terlepas dari klasifikasi pedagang besar dan pedagang kecil. Pedagang besar biasanya mempunyai modal yang cukup besar dan mempekerjakan banyak orang, sedangkan pedagang kecil, selain tidak mempunyai modal yang cukup banyak, juga biasanya tidak mempekerjakan banyak orang. Paling tidak ia dilakukan oleh seorang pedagang dengan satu atau dua orang pembantu.

Dalam konteks kedaerahan, sebagian besar mata pencaharian masyarakat di Kecamatan Sindangagung dan Garawangi, Kabupaten Kuningan Jawa Barat adalah bertani. Namun kesejahteraan ekonomi para petani masih secara umum memprihatinkan. Hal ini dikarenakan banyak faktor, yaitu: sebagian besar petani adalah sebagai buruh tani bukan pemilik tanah, harga bahan-bahan pertanian terutama pupuk pertanian yang senantiasa fluktuatif, mahal dan kadang-kadang menghilang di pasaran, ancaman gagal panen, dan lainlain sehingga mencekik perekonomian masyarakat. Artinya pengembangan ekonomi masyarakat di desa dirasakan sulit, sehingga mereka bermigrasi.

Untuk itu, masyarakat dari daerah kedua kecamatan ini ada sekitar lebih dari 2000 orang melakukan migrasi (merantau) ke kota-kota besar, diantaranya Yogyakarta untuk mencari penghidupan yang lain, yaitu sebagai pedagang bubur kacang ijo (burjo). Tradisi berwirausaha dan merantau ikut mengubah wajah desa-desa di Kecamatan Garawangi dan Ciawigebang. Mereka menemukan pola pengembangan masyarakat dengan cara migrasi. Sebagaimana dijelaskan Yen dan Luong bahwa pengembangan masyarakat desa harus disesuaikan dengan menganalisis konteks lokal dalam menangani kebutuhan masyarakat pedesaan (2008: 329-340).

Tradisi itu pula yang membawa orang-orang Kuningan berhasil menaklukkan kehidupan. Para perantau asal Kuningan dikenal sebagai 
wiraswasta tangguh dan ulung. Uniknya para perantau yang berprofesi sebagai pedagang burjo ini berasal dari desa-desa di kecamatan Sindangagung dan Garawangi.

Menarik, mencermati fenomena pedagang adalah pedagang burjo (bubur kacang ijo) sebagai salah satu pedagang yang berkatagori kecil di Yogyakarta. Saking menjamurnya warung-warung burjo di berbagai sudut Yogyakarta, maka tidak berlebihan kota ini tidak hanya dikenal sebagai kota pelajar atau mahasiswa tetapi juga dikenal dengan kota burjo. Fenomena ini menarik untuk diteliti secara cermat mengingat mobilitas penduduk di Yogyakarta tidak dapat dipisahkan dari gerakan migrasi dan jaringan relasi kelompok yang dilakukan para pedagang burjo demi mempertahankan hidupnya.

\section{B. Landasan Teori}

Pengembangan masyarakat ialah proses penguatan masyarakat secara berkelanjutan dan aktif berlandaskan kepada prinsip kerjasama, partisipasi, dan keadilan sosial yang setara. Pengembangan masyarakat mengekspresikan nilai proses belajar keberlanjutan, kerjasama, partisipasi, pilihan, kesempatan, kesetaraan, akuntabilitas, dan keadilan (Suharto, 2010: 65-66), berfokus pada hubungan pada inti fasilitasi pemahaman dan evaluasi, keterlibatan, pertukaran informasi dan pendapat, konsep, masalah atau proyek, dengan tujuan membangun modal sosial dan meningkatkan hasil sosial melalui pengambilan keputusan (Johnston, Lane, Devin, dan Beatson, 2018: 173).
Menurut neoclassical economic theory menyatakan bahwa alasan utama migrasi pekerja adalah perbedaan upah antara dua lokasi geografis. Perbedaan upah ini biasanya terkait dengan permintaan dan penawaran tenaga kerja geografis. Dapat dikatakan bahwa daerah dengan kekurangan tenaga kerja tetapi kelebihan modal memiliki upah relatif tinggi sedangkan daerah dengan pasokan tenaga kerja tinggi dan kelangkaan modal memiliki upah relatif rendah. Tenaga kerja cenderung mengalir dari daerah berupah rendah ke daerah berupah tinggi. Seringkali, dengan aliran tenaga kerja ini terjadi perubahan dalam pengiriman dan juga daerah penerima (Jennissen, R. 2007: 411 - 436).

Migrasi atau merantau adalah sulit untuk dilakukan pengukurannya, karena ia dapat diidentifikasikan dengan berbagai cara dan merupakan suatu perintiwa yang mungkin berkembang beberapa kali dijumpai dalam hidup seseorang. Oleh karena migrasi tidak dapat didefinisikan secara tepat, beberapa pakar mengusulkan agar migrasi dianggap sebagai bagian dari suatu rangkaian kesatuan yang meliputi semua jenis perpindahan penduduk, baik berdasarkan waktu (migrasi harian, periodik, musiman, jangka waktu panjang, tidak tetap dan permanen berdasarkan tempat (migrasi dari desa ke desa, desa ke kota, kota ke desa dan kota ke kota) maupun berdasarkan antara yang kembali ke tempat asal (sirkulasi) dan yang menetap di tempat lain (Yeoh, Huang, Lam, Theodora, 2018: 416).

Meskipun demikian, dari sudut sosiologi, ada enam unsur pokok yang melekat pada suatu migrasi, yaitu meninggalkan kampung halaman, dengan kemauan sendiri untuk jangka waktu 
lama atau tidak dengan tujuan mencari peng-hidupan, menuntut ilmu atau mencari pengalaman, biasanya dengan maksud kembali pulang dan migrasi itu sendiri dipandang sebagai lembaga sosial yang memberdaya.

Dari unsur-unsur pokok tersebut di atas paling tidak ada tiga motivasi orang melakukan migrasi, yaitu untuk mencari penghidupan, menuntut ilmu, mencari pengalaman. Arus migrasi telah menunjukkan bahwa keadaan ekonomi (mencari penghidupan) merupakan sebab utama terjadinya migrasi, disamping adanya juga karena alasan sosial lainnya, seperti ingin bergabung dengan temanteman atau anggota keluarga lainnya.

Berdasarkan hal di atas, ada dua teori migrasi yang telah dikemukakan para ahli yaitu:

\section{Teori Dorongan-Tarik}

Teori yang sangat populer ini telah dikemukakan pertama kali oleh Everett S. Lee dalam majalah Demography yang diterbitkan pada tahun 1966. Teori dorong tarik (push pull theory) bersifat sangat umum, dapat diterapkan pada semua bentuk migrasi. Pada dasarnya teori ini menerangkan tentang proses pengembilan keputusan bagi seseorang untuk melakukan migrasi yang mempengaruhi empat faktor; faktor yang terdapat pada daerah asal, faktor yang terdapat pada daerah tujuan, faktor rintangan dan faktor pribadi (Peter dan Donnelly, 2002: 132; Dowling, 2004: 266). Teori ini secara antropologis tidak cukup mampu menjelaskan peran dari gagasangagasan, budaya yang memotivasi orang untuk bermigrasi. Menurut White Ford (Pelly, 1994: 8), teori dorong-tarik dianggap terlalu simpatik, karena menganggap semua kekuatan sebagai kekuatan eksternal dan tidak memperhitungkan ada kehendak pribadi, padahal sesungguhnya kemiskinan belum cukup dianggap sebagai alasan abgi seseorang untuk melakukan migrasi.

2. Teori Berantai

Di negara-negara berkembang, terutama yang pada umumnya masih menganut sistem keluarga luas (extended family), teori ini sangat terkenal. Pada dasarnya teori berantai ini menjelaskan tentang proses pengambilan keputusan seseorang untuk meninggalkan kampung halamannya yang dihubungkan dengan keberadaan keluarga atau teman yang telah lebih dulu berada di daerah tujuan. Keberadaan keluarga atau teman di daerah. Tujuannya akan dapat menaikkan tingkat keberanian seseorang untuk meninggalkan daerah asalnya, karena selain mereka diharapkan dapat menolong mencarikan pekerjaan, juga diharapkan dapat memberikan bantuan ekonomi dan tempat tinggal pada saat berada di daerah tujuan untuk pertama kali. Teori berantai ini pada akhirnya membentuk kelompok kekeluargaan di daerah tujuan. Ikatan kelompok, seperti ini disebut Durkheim dengan istilah solidaritas mekanis, yaitu solidaritas yang didukung oleh persamaan dari individu-individu (Armstrong, 2012: 1). Pada sisi yang lain Geerts (Isaacs, 1993: 45) menyebutkan bahwa ikatan kekeluargaan di daerah rantau seperti itu diperoleh sebagai warisan dari sifat sosial yang telah ada. Ia dianggap sebagai kelangsungan yang berkesinambungan dari ikatan warisan 
yang berasal dari kelahiran di tengahtengah masyarakat yang berbicara dengan suatu bahasa, dialek dan praktik-praktik sosial tertentu.

\section{Metode Penelitian}

Penelitian dilakukan pada lima pedagang burjo di Dusun Papringan, Desa Caturtunggal, Kecamatan Depok, Sleman Yogyakarta. Pelaksanaannya dari 2 Agustus 2018 sampai 29 Desember 2018. Penelitian ini adalah penelitian kualitatif dengan pendekatan antropologis dan metode etnografi. Pengumpulan data dilakukan melalui pengamatan mendalam, wawancara mendalam, bebas atau tidak terstruktur.

\section{Temuan Penelitian}

Di Dusun Papringan ditemukan lima kios pedagang burjo. Ukuran luas dari masing-masing kios ini cukup bervariasi, dari yang berukuran 4 × 3 m sampai $7 \times 6$ m. Semuanya dalam bentuk bangunan yang sederhana. Dengan ukuran yang bervariasi itu, sebuah kios mempunyai peralatan yang tidak berbeda dengan kios burjo yang lainnya. Di dalamnya ditemukan kursi panjang atau kursi biasa tempat duduk para pembeli, meja hidangan dan berbagai alat masak serta alat dapur seperti piring, gelas, mangkuk, sendok, garpu, kompor, dan lain-lain. Semuanya disediakan sebagai alat utama untuk melayani para pembeli burjo.

Kios burjo yang cukup sederhana itu rata-rata diperoleh pedagang burjo dengan sistem kontrak selama setahun atau dua tahun. Harga kontrakan cukup elatif berbeda, tergantung tempat dan besarnya ukuran bangunan. Fasilitas yang diterima pedagang burjo dari kontrakannya itu biasanya hanya berupa bangunan kosong, kemudian dileng- kapinya dengan berbagai perlengkapan yang mendukung proses berdagang burjo, seperti kursi panjang dan meja hidangan. Tidak jarang dalam sebuah kios burjo ditemukan tape recorder dengan ukuran kompo atau tape deck, tv untuk menarik para pembeli, disamping juga sebagai teman berhibur ketika pembeli tidak ada.

Ciri utama yang dimiliki kios burjo yang dengannya dapat dibedakan dari kios dagang yang lainnya adalah ditemukannya sebuah spanduk berwarna kuning dengan ukuran rata-rata $2 \times 1 \mathrm{~m}$ yang dipajang di depan kios burjo. Di dalam spanduk itu tertulis kalimat yang berbeda-beda, namun yang jelas semua spanduk itu mencantumkan tulisan "Bubur Kacang Ijo" sebagai identitas utamanya.

Selain itu, di dalam sebuah kios burjo biasanya ditemukan daftar menu yang terpajang berhadapan dengan pembeli burjo. Di dalam daftar itu tertulis berbagai harga makanan yang disediakan kios burjo. Setelah diamati, ternyata kelima kios burjo Dusun Papringan itu memiliki daftar menu dengan harga yang sama untuk setiap jenis makanan yang sama. Tabel berikut ini meng-gambarkan daftar harga dan makanan yang disediakan dalam sebuah kios burjo.

Tabel 1

Daftar Menu Kios Burjo

\begin{tabular}{|c|c|c|}
\hline $\begin{array}{c}\mathrm{N} \\
\mathrm{o}\end{array}$ & Jenis Makanan & $\begin{array}{c}\text { Harga } \\
\mathrm{Rp}\end{array}$ \\
\hline 1 & Bubur Kacang Ijo* $^{*}$ & 4.000 \\
\hline 2 & Bubur Ayam $^{* *}$ & 7.000 \\
\hline 3 & Indomie Telur & 8.000 \\
\hline 4 & Indomie Rebus & 5.000 \\
\hline 5 & Indomie Goreng & 5.000 \\
\hline 6 & $\begin{array}{c}\text { Telur } \mathbf{1} / 2 \text { Matang (dua } \\
\text { butir) }\end{array}$ & 7.000 \\
\hline 7 & Es Teh Manis & 3.000 \\
\hline 8 & Susu & 3.000 \\
\hline 9 & Kopi & 3.000 \\
\hline
\end{tabular}


Keterangan:

* Biasanya dicampur dengan ketan hitam. Ada juga yang tidak tergantung permintaan pembeli

*** Tidak semua kios burjo ditemukan bubur ayam, hanya ada pada kios tertentu

Sayangnya, seiring perkembangan smartphone, akhir-akhir ini, warung burjo malah lucunya justru jarang menjual bubur kacang ijo. Pengakuan beberapa pedagang yang peneliti wawancarai, hal ini disebabkan kecenderungan konsumen di Yogyakarta lebih memilih makanan pokok berupa nasi dan lauk pauknya dibandingkan dengan makanan tambahan semisal bubur kacang ijo. "abdi ngadamel bubur kacang hejo ku bahan 1 kilo wae, nembe erep 3 dinten. Ayeuna mah kurang payu". (saya membuat bubur kacang ijo dengan bahan 1 kilo saja, baru habis (laku) 3 hari). Menu utama pengganti bubur kacang ijo ini adalah nasi telor, nasi sarden, dan indomie rebus atau goreng.

Dilihat dari status kependudukan, menurut keterangan yang diberikan Kepala Dusun, yaitu Giyono AS, pedagang burjo hanya terdaftar sebagai penduduk migrasi, sebab mereka itu bukan asli dusun Papringan. Untuk berdomisili di Dusun Papringan mereka cukup melapor kepada kadus sambil menyerahkan fotokopi KTP Kabupaten Kuningan, tanpa harus menyerahkan surat pindah dari daerah asal.

Kalau kita menelusuri Dusun Papringan, mulai dari

pembantu, Kirman berdagang burjo selama 24 jam. Ketiga pembantu itu semuanya berasal dari Sindangagung, Kuningan. Dipilihnya orang-orang yang sedaerah dan masih famili ini sebagai pembantunya karena hal itu akan memperlancar pekerjaan. Umumnya mereka sudah diketahui adat kebiasaannya, disamping hal itu juga dapat menolong mereka untuk mendapatkan pekerjaan.

Kirman sebagai juragan burjo dari Kuningan ini selalu memegang teguh persaudaraan. Meski sudah sukses, ia tidak lupa kepada tetangga dan sanak saudara di desa. "Daripada setamat SMA menganggur, lebih baik ikut saya. Gaji mungkin tidak banyak, namun nantinya bisa belajar berwiraswasta," ujar Kirman.

Tujuan utama Kirman marantau adalah untuk mencari penghidupan, disamping untuk menambah pengalaman. "Maksad kuring ngumbara ka lembur batur, nya teua aya sanes hoyong usaha kanggo ngahirupan anak pamajikan. Tur deui ngumbara teh tiasa nambihan pangalaman". (Maksud saya merantau ke daerah lain tidak lain untuk mencari pekerjaan, agar dapat memberi nafkah kepada anak istri. Disamping merantau itu sendiri dapat menambah pengalaman). Terlebih kondisi di daerahnya yang sulit untuk dijadikan tumpuan pendapatan ekonomi. Penghasilan sebagai buruh tani yang kecil dan hasil pertanian yang tidak menentu.

Meskipun Kirman merantau ke daerah lain, tapi ia punya maksud untuk pulang kembali ke kampung halamannya. Untuk itu, pada hari-hari besar tertentu seperti hari Lebaran dan Agustusan, tidak jarang Kirman menemui sanak familinya di Cidahu, Kuningan. 
Walaupun

sama-sama

menjalankan bisnis burjo, bukan persaingan yang muncul di antara perantau-perantau ini. Rasa senasib justru lebih mengemuka. Saat sakit, ada karyawan burjo, dibantu teman seperantauannya. Ketika krisis moneter melanda, ia tidak pernah mem-PHK karyawan. Dalam keadaan sulit, karyawannya rela bekerja walaupun gajinya tertunda. Dari cara seperti inilah perantau-perantau asal Kuningan membangun gurita bisnis yang tahan krisis dan kokoh. Disamping mencari rezeki, mereka juga membantu kehidupan teman sekampung.

Selama merantau ke Yogyakarta, Kirman yang hanya tamatan SD ini mem-punyai kebahagiaan tersendiri. Di Yogyakarta, ia merasa aman berdagang burjo karena di sini jarang terjadi kerusuhan. Oleh karena itu, untuk merantau, Kirman lebih baik memilih Yogyakarta daripada daerah lainnya.

Adalah Abba (65 tahun), pimpinan Arya Kemuning yang dulu banyak membantu Kirman untuk berdagang burjo di Yogyakarta. Menurut Kirman, Arya Kemuning adalah sebuah paguyuban sebagai pemberdaya dan pengembangan masyarakat bagi pedagang burjo yang berasal dari Kuningan. Abbaslah (hingga sekarang Kirman belum ketemu kembali) orang yang memilihkan lokasi untuknya berdagang burjo. Pada saat itu, melalui Arya Kemuning sebagai lembaga pemberdaya masyarakat, diadakan arisan dan iuran diantara para pedagang burjo di Yogyakarta yang berasal dari Kuningan.
1. Darma

Kios burjo milik Darma terletak di jalan Petung di belakang KFC, tepatnya berada di depan STIPER. Darma yang berasal dari Desa Pakembangan Garawangi, Kuningan kini berusia 45 tahun. Dia merantau ke Yogyakarta pada tahun 1996 mengikuti pamannya, Dullah (60 tahun) yang sudah berdagang burjo selama enam tahun di jalan Gejayan. Selama dua tahun mengikuti pamannya, Darma berusaha mendirikan kios burjo tersendiri. Namun karena modal diperkirakan belum cukup, maka ia rembukan modal dengan dua orang teman dari daerah asalnya, yaitu Ujang Wawa (40 tahun) dan Ujang Dede (38 yahun). Di permulaan jalan Petung inilah mereka bertiga mengelola sebuah kios burjo yang cukup sederhana, dan oleh karena Darma lebih tua usianya daripada kedua temannya, maka ia dipilih sebagai pemimpin-nya.

Melalui kerjasama dengan dua orang temannya, Darma mampu membuka kios burjonya selama 24 jam dengan sistem 2 banding 1, artinya dua orang berdagang dan satu lagi istirahat, demikian seterusnya secara bergiliran.

Ketika ditanya apakah ada niat untuk kembali ke kampung halaman, Darma menginformasikan bahwa maksud itu sudah ada sejak pertama kali pergi merantau, tapi waktu mudiknya tidak tentu. Yang jelas Darma selalu mudik setiap bulan untuk mengirim uang kepada tiga orang adiknya yang sedang sekolah di Ciawigebang, daerah kelahirannya.

Kedatangan Darma ke Yogyakarta ini karena melihat potensi ekonomi dengan banyaknya pelajar 
dan mahasiswa di kota ini. Sementara di daerahnya, ia sulit mengembangkan usaha.

Keberadaan Arya Kemuning sebagai paguyuban yang ikut memfasilitasi para pedagang burjo ada kaitannya dengan Darma. Dia tahu tentang keberadaan Arya Kemuning. "Muhun sok aya sih ti pengurusna anu sok ngayakeun riungan tur arisan kanggo maheutkeun silaturahmi”. (ya memang ada dari pengurusnya yang suka mengadakan kumpulan dan arisan untuk mempererat silaturahmi).

2. Edo

Kios burjo Edo terletak di jalan Petung, tepatnya di pertigaan jalan Ori II di samping warung makan Warto. Edo yang kini berusia 70 tahun merantau ke Yogyakarta bersama isterinya, Acah (60 tahun) pada tahun 1993. Edo yang lulusan SD ini berdagang burjo karena diajak kakak isterinya, Ohan (55 tahun) yang kini tengah berdagang burjo di dusun Mrican. Di samping berdagang burjo, Edo juga membuka kios kecil berjualan rokok.

Oleh karena hanya berdua dengan isterinya, maka Edo hanya mampu berdagang sampai jam 24.00. Menurutnya, terlalu repot kalau harus buka burjo selama 24 jam. Adapun pembagian waktu berdagang biasanya dibagi dua; siang dan malam. Siang hari dari jam 6.00 sampai sore jam 16.00 adalah jadwal bu Acah, sedangkan malam hari dari jam 16.00 sore sampai jam 24.00 malam adalah giliran Edo.

Menurut informasi yang dikemukakannya, Edo dulunya adalah seorang petani di daerah asalnya, Garawangi, Kuningan. Akan tetapi kemudian ditawari "ngumbara" oleh kakak isterinya ke Yogyakarta. Oleh karena itu, merantau bagi Edo hanyalah untuk mencari peng-hidupan lain yang lebih baik daripada penghidupan yang sulit di desa.

Dalam perantauannya di daerah lain, Edo ternyata masih ingat dengan kampung halamannya. Buktinya setiap dua bulan sekali beliau menyempatkan waktu untuk mudik ke Kuningan. Disamping untuk menemui sanak familinya, yang terpenting dalam mudiknya bagi Edo adalah mem-beri nafkah kepada dua anak gadisnya yang hidup bersama kakek neneknya. Diakui Edo bahwa berdagang burjo dirasa agak "seuseut" (sulit), sebab tidak jauh dari kios burjonya terdapat kios burjo milik Darma.

Ditanya tentang peguyuban pedagang burjo Arya Kemuning, Edo tahu sekali tentang hal itu, walaupun dia datang ke Yogyakarta diajak oleh kakak iparnya. "Datangnya ke Yogyakarta dengan sejumlah modal kecil bersama isteri, kemudian berdagang burjo, itu saja". Demikian informasi yang dikemukakan Edo. Eksistensi paguyuban ini menampung keluhan dari para anggotanya untuk sama-sama maju dalam usaha burjo.

3. Elon

Kios burjo milik Elon terletak di jalan Wulung di samping rumah nomor 4. Daerah ini merupakan pangkalan tukang becak. Elon yang berusia 47 tahun in datang dari Sindangagung ke Yogyakarta pada bulan Agustus 1998. Dia berdagang burjo tanpa diajak oleh siapapun. Hanya saja ia pernah mendengar bahwa pedagang burjo itu rata-rata berasal dari Sindang-agung dan Garawangi Kuningan. Elon yang 
hanya tamatan SD ini merantau ke Yogyakarta ditemani oleh adik perempuannya, Iim (44 tahun), yang senantiasa membantu dalam proses berdagang burjo dan didampingi bantuan penyuluhan dari Arya Kemuning.

Oleh karena hanya berdua, kios burjo Elon dibuka berbeda dengan yang lainnya. Jadwal tutupnya tidak tentu, tergantung kondisi fisik yang dirasakan dan ada tidaknya orang yang begadang di pinggir jalan. " $D i$ dieu mah nutupnya heunteu tangtu. Kadang-kadang tutup tabuh 12 wengi, atanapi dugi ka tabuh 2 wengi. Upami seueur anu begadang biasana tutup dugi ka tabuh 2 wengi". (Di sini jam tutupnya tidak tentu. Kadang-kadang jam 12 malam, atau sampai jam 2 malam. Jika banyak orang yang begadang biasanya tutup sampai jam 2 malam).

Sebelum ke Yogyakarta, Elon yang berasal dari Sindangagung, Kuningan ini pernah merantau ke daerah lain seperti Jakarta dan Cilegon. Di Jakarta dan Cilegon, Elon tidak menjadi pedagang, tapi bekerja sebagai buruh bangunan. Dibandingkan kedua kota di atas, suasana di Yogyakarta kiranya lebih menyenangkan. Selain dirasakan aman dan ramah, Yogyakarta juga merupakan tempat yang layak untuk berdagang. Hal ini, menurut Elon juga merupakan tempat yang layak untuk berdagang. Hal ini, menurut Elon yang ingin mudik bila Lebaran tiba, disebabkan oleh keberadaan Yogyakarta sebagai kota pelajar. Yogyakarta itu cocok untuk berdagang. Berdagang apapun, ter- masuk burjo, di Yogyakarta akan selalu banyak diminati pembeli.

4. Dadang

Kios burjo Dadang terletak diujung jalan Beo, tepatnya di belakang Apartemen Sejahtera. Daerah ini merupakan daerah perumahan yang cukup rapi. Di samping para mahasiswa, daerah ini juga dihuni para pagawai, naik negeri maupun swasta. Dadang yang berusia 50 tahun datang ke Yogyakarta 4 tahun yang lalu, yaitu 1995. Kios burjonya dibantu oleh dua orang pembantu, satu orang-orang yang sekampung halaman, yaitu Garawangi, Kuningan.

Dadang yang mengaku lulusan SD ini, dengan dibantu dua orang pembantunya, mampu membuka kios burjo secara full time. Selama empat tahun menjadi pedagang burjo, ia merasakan ada peningkatan dalam tarap hidupnya, dibandingkan ketika berada di kampung halamannya.

Apabila hari Lebaran menjelang tiba, Dadang biasanya siap-siap untuk mudik ke daerah asalnya di Garawangi. Pada hari raya, menurut Dadang, tidak enak kalau kita tetap berdagang. "Kuring teh kan jalmi Islam. Piraku dinten Boboran heunteu dimulyakeun. Teu raos kadanguna upami kuring icalan pas dinten Boboran, mendingan balik ka lembur". (Saya ini kan Islam. Masa iya hari raya Lebaran tidak dihormati. Tidak enak kedengarannya kalau kita tetap berdagang pada hari raya, lebih baik mudik ke kampung halaman).

Merantau menurut Dadang pada intinya untuk meningkatkan tarap hidup. Untuk ini yang dapat dilakukan Dadang hanyalah berdagang burjo, tidak memerlukan keahlian khusus, 
mengingat ia hanya lulusan SD. Kemudian berdagang yang paling enak adalah buka kios sendiri, seperti kios burjo ini.

Berdagang burjo di Yogyakarta ini, sebagaimana diakuinya, sesuai dengan keinginannya sendiri. Tidak ada orang atau sanak famili yang mengajaknya. Ketika ditanya apakah kenal dengan Darma yang berdagang burjo di jalan Petung yang juga berasal dari Garawangi, Dadang menjawab mengenalnya. Dia tertarik datang ke Yogyakarta karena sosialisasi paguyuban Arya Kemuning, di samping juga sebagai kota wisata dan kota pelajarnya, dan kiranya di kota seperti ini berdagang apapun akan selalu laris.

\section{E. Pembahasan}

1. Pola Migrasi Pedagang Burjo

\section{a. Tipe Migrasi}

Migrasi dapat dipandang sebagai bagian dari suatu rangkaian kesatuan yang meliputi semua jenis perpindahan penduduk, yang digambarkan sebagai mobilitas penduduk. Untuk mempermudah kajian alangkah baiknya migrasi di sini terbagi kepada tiga tipologi, yaitu berdasarkan waktu, berdasarkan tempat dan berdasarkan menetap atau tidak. Dari ketiga tipologi migrasi ini, arus perpindahan penduduk pedagang burjo di Yogyakarta kiranya dapat dianalisa.

1) Berdasarkan Waktu

Dari segi waktu, kelima pedagang burjo di dusun Papringan yang ternyata semuanya berasal dari Sindangagung dan Garawangi

Kabupaten Kuningan, dapat dikate-gorikan sebagai tipe migrasi periodik dan tipe migrasi tidak tetap. Kirman, Elon, dan Dadang yang selalu pulang ke daerah asalnya setiap hari raya Lebaran dan Edo yang setiap dua bula sekali mudik, termasuk pada katagori migrasi tipe migran tidak tetap, karena ia tidak mempunyai waktu tertentu untuk kembali ke daerah asalnya.

2) Berdasarkan Tempat

Yogyakarta dikenal sebagai kota pelajar, perjuangan, batik, budaya dan kota wisata (Murdiyanto, 2017: xii). Dengan predikat seperti itu, layaknya sebuah kota, Yogyakarta banyak diminati orang dikunjungi. Lima pedagang burjo di Dusun Papringan yang semuanya berasal dari Kuningan datang ke Yogyakarta dengan tujuan yang beragam. Kelimanya dapat disebut sebagai migran, yaitu melakukan perpindahan penduduk dari Kuningan ke Yogyakarta. Dilihat dari segi tempat, mereka termasuk pada katagori migrasi dari desa ke kota, atau sering disebut dengan urbanisasi.

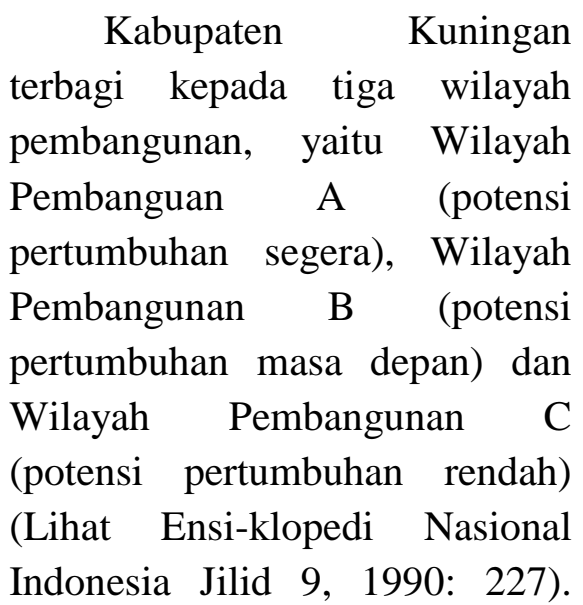


Kecamatan Garawangi yang merupakan daerah asal Edo, Darma, dan Dadang masuk pada Wilayah Pembangunan A, dan Kecamatan Sindangagung yang merupakan daerah Kirman dan Elon masuk pada Wilayah Pembangunan C.

Dari temuan di atas hal ini menunjukkan bahwa migrasi yang dilakukan oleh para pedagang Burjo dari Sindangagung dan Garawangi Kuningan ke Yogyakarta termasuk dalam katagori migrasi internal. Sebagaimana dijelaskan World Economic Forum (2017: 14) migrasi yang terjadi di suatu negara dari kota ke desa, kota ke kota, desa ke kota, atau desa ke kota. Istilah yang terkait dengan migran yang tiba di tempat tujuan adalah "migrasi internal".

3) Berdasarkan Menetap atau tidak

Data-data hasil wawancara terhadap lima pedagang burjo di dusun Papringan menunjukkan bahwa kelima pedagang itu adalah penduduk asli Kabupaten Kuningan, bukan penduduk Dusun Papringan. Dalam hal ini, ketika ditanya apakah ada hasrat untuk kembali ke kampung halaman ataukah mau menetap di Yogyakarta, semuanya mengatakan bahwa kampung halaman (daerah asal) merupakan tempat kelahiran. "Sejauh-jauh burung terbang, pada akhirnya akan kembali ke sangkarnya juga" kiranya merupakan semboyan yang dijadikan pegangan oleh kelima pedagang burjo itu dalam rangka perantauannya. Dengan demikian, dari segi ini, dapat dikatakan bahwa migrasi yang mereka lakkukan termasuk pada katagori migrasi tipe sirkulasi, yaitu migrasi yang dilakukan migran dengan maksud untuk kembali ke daerah asalnya.

b. Tujuan Migrasi

Tidak semata-mata orang melakukan suatu aktivitas kalau tidak dilandasi oleh tujuan yang ingin dicapainya. Ada beberapa tujuan orang melakukan migrasi, diantaranya adalah mencari penghidupan, menuntut ilmu dan mencari pengalaman. Tujuantujuan ini sebagiannya merupakan tujuan yang hendak dicapai oleh kelima pedagang burjo di dusun Papringan. Mencari penghidupan misalnya, merupakan tujuan yang telah dipilih oleh empat pedagang burjo. Mereka adalah Kirman, Darma, Edo dam Elon. Adapun Dadang melakukan migrasi, selain untuk mencari penghidupan, juga untuk mencari pengalaman sebagai bekal hidup. Dengan demikian, mencari penghidupan dan mencari pengalaman merupakan dua tujuan yang hendak dicapai kelima pedagang burjo di dusun Papringan.

Kedua tujuan migrasi di atas dipilih lima pedagang burjo di dusun Papringan kiranya tidak terlepas dari pengaruh faktor pendidikan yang mereka miliki. Dipilihnya berdagang burjo sebagai pekerjaan merupakan bukti adanya pengaruh faktor pendidikan terhadap tujuan migrasi yang hendak mereka capai. Berdagang burjo memang merupakan 
pekerjaan yang mudah dan sederhana. Untuk dapat melaksanakan pekerjaan ini tidak diperlukan keterangan khusus yang diperoleh melalui jenjang akademik secara formal. Oleh karena kelima pedagang burjo itu rata-rata memiliki pendidikan SD, maka adalah wajar apabila berdagang burjo dipilihnya sebagai pekerjaan dalam rangka mencari penghidupan di daerah rantau. Berikut ini dikemukakan tabel tentang jenjang pendidikan pedagang burjo di dusun Papringan.

Tabel 2

Jenjang Pendidikan Pedagang Burjo

\begin{tabular}{|c|l|c|}
\hline No & \multicolumn{1}{|c|}{ Nama } & Jenjang Pendidikan \\
\hline 1 & Kirman & SD \\
\hline 2 & Darma & SMP \\
\hline 3 & Edo & SD \\
\hline 4 & Elon & SD \\
\hline 5 & Dadang & SD \\
\hline
\end{tabular}

c. Motivasi Migrasi

Manusia adalah makhluk bertingkah laku untuk memenuhi kebutuhannya. Ia bertingkah laku disebabkan oleh adanya motivasi yang telah mendorongnya untuk berbuat sesuatu, baik motivasi yang bersifat instrinsik maupun yang bersifat ekstrinsik. Dalam sebuah proses migrasi, diantaranya terdapat dua teori yang membuat orang melakukan migrasi, yaitu teori dorong-tarik dan teori berantai. Untuk menganalisa motivasi migrasi yang dilakukan lima pedagang burjo di dusun Papringan kiranya kedua teori itu dapat dipergunakan.

1) Teori Dorong-Tarik
Teori ini menyebutkan bahwa seseorang melakukan migrasi karena adanya berbagai faktor mendorong dan yang menariknya. Daerah asal merupakan faktor pendorong dan daerah tujuan merupakan faktor penarik. Untuk fenomena pedagang burjo di dusun Papringan, Elon dan Dadang melakukan migrasi dari Kuningan ke Yogyakarta sesuai dengan teori ini. Elon meninggalkan kampung halamannya di Cidahu, Kuningan, terdorong oleh kondisi daerah asalnya yang dianggapnya tidak mampu meningkatkan taraf hidup-nya menuju sumberdaya manusia yang berkualitas secara non fisik. Seperti telah diungkapkan bahwa Sindangagung merupakan salah satu kecamatan yang berada di Kabupaten Kuningan yang tergolong pada katagori Wilayah Pembangunan $\mathrm{C}$, yaitu wilayah yang memiliki potensi pertumbuhan rendah. Kemudian Elon tertarik oleh daerah lain, yaitu Yogyakarta sebagai daerah tujuan migrasinya. Ketertarikan Elon oleh Yogyakarta, sebagaimana diakuinya, disebabkan karena Yogyakarta termasuk kota yang aman dan ramah, disamping sebagai kota pelajar. Keadaan Yogyakarta seperti itu kiranya yang membuat Elon datang ke Yogyakarta. Ditambah lagi Elon telah melakukan suatu perbandingan antara Yogyakarta dengan Jakarta dan Cilegon, dan 
dari perbandingan itu ternyata Yogyakarta lebih menyenangkan dan dapat membuat lebih kerasan.

Adapun Dadang merantau ke Yogyakarta tertarik oleh keberadaan Yogyakarta sebagai kota wisata, disamping sebagai kota pelajar. Predikat yang disandangkan kepada Yogyakarta seperti ini telah membuat berdagang apapun menjadi laris, termasuk berdagang burjo.

2) Teori Berantai

Pada intinya teori ini menegaskan bahwa seorang melakukan migrasi karena adanya famili atau teman yang telah lebih dahulu berada di daerah tujuan. Berdasarkan teori ini bahwa terjadinya proses migrasi di suatu wilayah terkait dengan keberadaan kawan atau famili yang sudah menetap lebih dulu di wilayah tersebut. Migrasi pemula sebagai pelopor akan menarik penduduk dari daerah asal yang mengakibatkan munculnya pola migrasi berantai (chain migration) (Zhao, Yaohui. 2003: 500).

Kirman dan Darma adalah dua orang pedagang burjo di dusun Papringan yang datang ke Yogyakarta sebagai perantau karena adanya famili atau teman. Kirman telah diajak berdagang burjo oleh Abbas, mantan pimpinan Arya Kemuning sebelum tahun 1994-an. Arya Kemuning sebagai sebuah paguyuban yang mewadahi para pedagang burjo yang berasal dari
Kuningan kiranya masih esktra dan mampu menyalurkan aspirasi para warganya. Sebagai buktinya adalah Kirman yang kini berada di Yogyakarta sebagai seorang pedagang burjo berkat peran dan jaringan relasi kelompok yang telah dibentuk Arya Kemuning. Keberadaan Arya Kemuning sebagai pengikat jaringan relasi kelompok diantara para pedagang dapat berlangsung cukup baik. Hal itu disebabkan oleh kemampuan yang cukup baik dari pimpinan Arya Kemuning dalam bidang manajemen, disamping oleh melemahnya rasa ketertarikan dari anggota-nya.

Sedangkan Darma datang ke Yogyakarta karena termotivasi oleh keberadaan pamannya yang lebih dahulu melakukan migrasi ke kota gudeg ini. Sesungguhnya para migran yang melakukan migrasi berdasarkan teori ini akan dapat membentuk sebuah jaringan sosial yang berupa kelompok etnis. Jaringan kelompok etnis ini sesungguhnya terbentuk dan menjadi kuat berkat adanya rasa solidaritas mekanis dan pengembangan masyarakat melalui paguyuban. Di daerah perantauan mereka akan mempunyai perasaan senasib dan sepenanggungan. Oleh karena itu, apabila mereka lebih cenderung memperbesar dan memperkuat persamaan yang ada pada mereka daripada perbedaannya, maka jaringan 
kelompok etnis itu akan tetap eksis secara terorganisasi. Kalau toh terjadi perbedaan, maka perbedaan itu tidak akan sampai membuat mereka jatuh pada sebuah konflik yang dapat memisahkan rasa solidaritas itu.

3) Teori Campuran

Yang dimaksud teori campuran ini adalah gabungan antara teori dorong-tarik dengan teori berantai. Seorang individu melakukan migrasi bukan hanya karena adanya dorongan dari daerah asal dan tarikan dari daerah tujuan, tetapi juga karena adanya famili atau teman di daerah rantau. Hal ini terjadi pada Edo, seorang pedagang burjo di dusun Papringan yang berasal dari Garawangi, Kuningan. Pada awalnya Edo seorang petani di daerah asalnya, tetapi karena menjadi petani dianggapnya belum mampu mencukupi kebutuhan hidupnya dan tidak dapat meningkatkan tarap hidupnya, maka Edo termotivasi untuk merantau. Ditambah lagi kepergian Edo ke daerah rantau diajak oleh kakak iparnya, yaitu Ohan. Berbagai motivasi telah terpatri dalam benak Edo, baik dari dalam maupun dari luar. Motivasi ini telah membuat Edo lebih kuat melakukan migrasi, maka migrasi seperti yang dialami Edo ini akan bersifat lebih lama dan membuatnya kerasan berasa di daerah orang lain. Oleh karena itu, seandainya diperantauan ia mengalami hambatan dan kendala, maka kendala itu dianggapnya bahwa dirinya di daerah rantau tidak hidup sendirian, tapi ada famili dan temannya yang akan membantunya.

d. Makna Migrasi bagi Pedagang Burjo

Dari beberapa analisa terhadap lima pedagang burjo di Dusun Papringan di atas, baik analisa tipe migrasi, tujuan maupun motivasinya, maka sesungguhnya di sini dapat dikatakan bahwa para pedagang burjo itu ternyata mempunyai persepsi tersendiri terhadap migrasi atau merantau. Merantau bagi mereka mempunyai makna sebagai upaya untuk meningkatkan kualitas hidup secara nonfisik. Sebagai makhluk, manusia yang selalu dituntut untuk produktif dan prestatif, migrasi dalam pandangan mereka merupakan suatu aktivitas yang dapat meningkatkan tarap hidup mereka lebih sejahtera, dibandingkan daripada sebelumnya keitka berada di daerah asal.

Tipe migrasi sirkulasi yang dipilih oleh kelima pedagang burjo itu merupakan bukti bagi besarnya rasa ketertartarikan mereka akan daerah asalnya. Kemudian rasa solidaritas yang dipupuk oleh paguyuban dan etnisitas kedaerahan telah menyebabkan terbentuknya jaringan relasi kelompok di antara pedagang burjo di Yogyakarta. Secara eksplisit memang jaringan itu tidak dapat berlangsung lama, yaitu dengan hilangnya paguyuban Arya Kemuning. Akan tetapi, pada suatu saat paguyuban seperti ini akan muncul lagi dalam bentuk 
baru selama para migran itu masih mempunyai rasa solidaritas mekanis dan ketertarikan dengan daerah asalnya.

2. Pengembangan Masyarakat Sindangjawa dan Garawangi

Pengembangan masyarakat Sindangjawa dan Garawangi mengarah kepada pengembangan ekonomi melalui migrasi ke daerah lain, dalam hal ini Yogyakarta yang difasilitasi oleh solidaritas bingkai etnis, kekeluargaan, dan berdiaspora melalui paguyuban. Hasil bisnis burjo cukup besar. Apabila satu warung dapat menghasilkan $\mathrm{Rp} 4$ juta per bulan, jumlah total pendapatan 1.000 warung dalam setahun mencapai $\mathrm{Rp}$ 48 miliar. Jumlah ini hampir sama dengan Pendapatan Asli Daerah (APBD) Kabupaten Kuningan.

Para perantau itu pun membawa perubahan besar bagi kampung halaman. Di sejumlah desa seperti Kertayasa Sindangagung dan desadesa Garawangi, jalan aspal sudah bukan lagi hal baru. Parabola atau mobil roda empat menghiasi rumahrumah para juragan burjo yang sekarang bergelar haji. Apabila 20 tahun kemudian lulus SMA saja sudah luar biasa, kini menurut kuwu Kertayasa Singdangagung Oteng Sutara (Wawancara 2 November 2018) telah biasa jika pemuda-pemuda kuliah di luar kota.

Bupati Kuningan Acep Purnama mengakui, perantau-perantau sudah menghidupkan bisnis transportasi dan mengurangi pengangguran. Mereka menggerakkan roda ekonomi rakyat Kuningan secara keseluruhan. Tradisi merantau dan berwirausaha itulah yang mengubah wajah kehidupan masyarakat Kuningan. Seperti halnya penjual-penjual bakso dan jamu dari Wonogiri, atau pengusaha warung Tegal dari Jawa Tengah, mereka memilih tidak berpangku tangan. Mereka berdiaspora membangun kemandirian, mengubah wajah suram tanah asal menjadi suatu harapan (Wawancara 3 November 2018).

\section{F. Kesimpulan}

Sebagai sebuah aktivitas, kehidupan sosial ekonomi pedagang burjo di Dusun Papringan mempunyai liku-liku tersendiri yang berbeda dengan pedagang lainnya. Mereka pada umumnya membuka kios burjo selama 24 jam dengan dibantu satu sampai tiga orang pembantu. Kios burjo yang merupakan bangunan sederhana diperoleh pedagang burjo melalui sistem kontrak selama satu atau dua tahun. Di depan kios burjo biasanya terpajang spanduk berwarna kuning yang didalamnya selalut tertulis "Bubur Kacang Ijo". Dari kelima pedagang burjo di dusun Papringan, semuanya adalah kaum pria yang rata-rata berpendidikan SD.

Dari segi waktu, lima pedagang burjo di dusun Papringan yang telah melakukan migrasi dari Kuningan ke Yogyakarta termasuk pada katagori migrasi tipe periodik dan tipe migrasi tidak tetap. Dari segi tempat, mereka dapat dipandang sebagai kaum urban yang telah melakukan migrasi dari desa ke kota. Adapun dari segi menetap atau tidak, para pedagang itu telah memilih megrasi sirkulasi agar dapat berkumpul kembali satu waktu bersama sanak famili di daerah asalnya.

Pada umumnya, lima pedagang burjo di dusun Papringan melakukan migrasi karena dua motivasi, yaitu instrinsik dan 
ekstrinsik. Kedua motivasi ini telah dipengaruhi dua teori migrasi yang dikemukakan para ahli, yaitu teori dorong-tarik dan teori berantai. Berdasarkan teori dorong-tarik, para pedagang burjo termotivasi merantau ke Yogyakarta karena keberadaan daerah asal-nya yang rata-rata dianggap kurang mem-berikan peluang bagi mereka untuk me-ngembangkan potensi yang dimiliki, di samping karena Yogyakarta itu sendiri mem-punyai daya tarik yang begitu kuat bagi mereka. Sedangkan berdasarkan teori berantai para pedagang itu melakukan migrasi karena telah adanya sanak famili atau teman mereka di Yogyakarta. Seandainya kedua teori migrasi di atas tergantung dalam diri seseorang, maka motivasi yang dimilikinya untuk melakukan migrasi sangatlah kuat. Jadi disini antara teori dorong-tarik dan teori berantai dapat dipadukan.

Ada dua tujuan yang telah ditentukan para pedagang burjo di dusun penghidupan dan mencari pengalaman. Kedua tujuan ini sebegitu kuta terpatri dalam diri mereka sehingga mereka mampu dalam rangka waktu yang lama menekuni pekerjaannya sebagai pedagang burjo.

Melihat kepada teori berantai yang telah melandasi prilaku migrasi para pedagang burjo di dusun Papringan, maka sesunggunya dengan itu berarti mereka telah membuat sebuah jaringan relasi kelompok pedagang burjo, baik secara eksplisit maupun implisit. Secara eksplisit, mereka telah terbina dalam Arya Kemuning, sebuah paguyuban pedagang burjo yang telah eksis hingga tahun 1994-an, dan secara implisit mereka senantiasa telah terikat oleh rasa solidaritas mekanis, disebabkan oleh adanya persamaan-persamaan yang terdapat di kalangan mereka. Selama solidaritas itu terpatri dalam jiwa mereka, maka selama itu pula jaringan relasi kelompok yang dibentuknya tetap eksis. Dari teori berantai inilah senantiasa terjawab mengapa pedagang burjo di Yogyakarta selalu berasal dari Kuningan. Ditambah lagi, pada sisi yang lain, dipilihnya migrasi sirkulasi merupakan bukti kuatnya etnisitas kedaerahan para pedagang burjo. Dari sini dapat dimengerti bahwa ternyata pada pedagang itu mempunyai persepsi tersendiri terhadap migrasi, yaitu sebagai upaya pengembangan masyarakat untuk mening-katkan tarap hidup di daerah rantau melalui sistem jaringan relasi kelompok.

\section{DAFTAR PUSTAKA}

Armstrong, Neshonia. 2012. The Importance of Extended Families in the African American Community: A Qualitative Analysis Using Social Learning Theory". dalam Proceedings on The National Conference On Undergraduate Research (NCUR) 2012 Weber State University, Ogden, Utah March 29-31, 2012. Department of Political Science Howard University. Washington, D.C. 20059

Dowling, Grahame Robert. 2004. The Art and Science of Marketing. Oxford, UK: Oxford University Press.

Ensiklopedi Nasional Indonesia. Jilid 9 dan 17. Jakarta: Cipta Adi Pustaka.

Isaacs, Harold R. 1993. Pemujaan terhadap Kelompok Etnis Identitas Kelompok 
dan Perubahan Politik. Cet. I. Jakarta: Yayasan Obor Indonesia.

Jennissen, R. 2007. "Causality Chains in the International Migration Systems Approach," dalam Population Research and Policy Review 26 (4). $411-436$.

Johnston, K. A., Lane, A. B., Devin, B., \& Beatson, A. 2018. "Episodic and Relational Community Engagement: Implications for Social Impact and Social License," In K. A. Johnston \& M. Taylor (Eds.), The Handbook of Communication Engagement. Hoboken, NJ: Wiley: 169-185.

Murdiyanto, H.Y. Agus. 2017. Budaya Lokal dalam Perkembangan Pariwisata di Yogyakarta. Yogyakarta: Ilmu Sejarah FIS UNY.

Pellu, Usman. 1994. Urbanisasi dan Adaptasi Peranan Misi Budaya Minangkabau dan Mandailing. Cet I. Jakarta: LP3IS.

Peter, J. Paul; James H. Donnelly. 2002. A Preface to Marketing Management. McGraw-Hill Professional.

Suharto, Edi. 2010. Membangun Masyarakat Memberdayakan Rakyat. Bandung: Alfabeta.

World Economic Forum. 2017. Migration and Its Impact on Cities. Cologny/Geneva Switzerland

Yen, N. T. K.; Luong, P. Van. 2008. "Participatory Village and Commune Development Planning (VDP/CDP) and its Contribution to Local
Community Development in Vietnam", dalam Community Development Journal. 43 (3): 329340.

Yeoh, Brenda S. A.; Huang, Shirlena; Lam, Theodora. 2018. "Transnational Family Dynamics in Asia", dalam Triandafyllidou, Anna. Handbook of Migration and Globalisation. Handbooks on Globalisation Series. Cheltenham, UK: Edward Elgar Publishing.

Zhao, Yaohui. 2003. "The Role of Migrant Networks in Labor Migration: The Case of China", dalam Contemporary Economic Policy. 21 (4): 500-511. 